\title{
Alterations in endothelium-associated proteins and serum thyroid hormone concentrations in anorexia nervosa
}

\author{
BY GEN KOMAKI, HAJIME TAMAI, TOSHIO MUKUTA, \\ NOBUYUKI KOBAYASHI, KENJI MORI AND TETSUYA NAKAGAWA \\ Department of Psychosomatic Medicine, Faculty of Medicine, Kyushu University, Fukuoka, Japan \\ AND LINDY F. KUMAGAI \\ Department of Internal Medicine, School of Medicine, University of California, Davis (LFK), \\ Sacramento, CA, USA
}

(Received 2 January 1991-Accepted 5 July 199I)

\begin{abstract}
Plasma concentrations of endothelium-associated proteins (EAP) (plasma fibronectin (PFN), angiotensin-converting enzyme, factor VIII-related antigen (F VIII-R : Ag)) and tissue plasminogen activator and serum thyroid hormone concentrations were studied in nine patients with anorexia nervosa (AN), before and after weight gain. Before weight gain (-35.9 (SE 2.3)\% of standard body-weight) PFN was significantly reduced and F VIII-R:Ag was significantly increased in AN patients compared with the concentrations in control subjects $(211.5$ (SE 14.9) v. 274.7 (SE 16.6) $\mu \mathrm{g} / \mathrm{ml}, P<0.05 ; 129.2$ (SE 14.1) $v$. 88.2 (SE 9.7) \%, $P<0.05$ respectively). Serum triiodothyronine (T3) and free T3 levels were also significantly lower before weight gain in AN patients (0.85 (SE 0.07) v. 1.53 (SE 0.08$) \mathrm{nmol} / \mathrm{l}, P<0.001$; 2.57 (SE 0.23) v. 5.31 (SE 0.34) pmol/l, $P<0.001$ respectively), although serum thyroxine (T4), free T4, and thyrotropin concentrations were within the normal range throughout the study periods. Following weight gain, PFN and F VIII-R : Ag concentrations normalized as did the thyroid hormone levels. The incremental changes in PFN levels correlated significantly with those in serum thyroid hormone concentrations (T3, $r 0.79, P<0.01$; free T3, $r 0.84, P<0.01)$. These findings suggest that PFN levels may be directly related to serum $\mathrm{T} 3$ concentrations in AN patients.
\end{abstract}

Endothelium-associated proteins: Serum thyroid hormone: Anorexia nervosa

Malnutrition is the major feature in anorexia nervosa (AN) patients (Newman \& Halmi, 1988). Protein intake, however, is usually adequate and vitamin deficiency is rare (CurranCelentano et al. 1985), so the condition is different from protein-deficient malnutrition such as marasmus (Waterlow, 1972). The endothelial vessel wall is a metabolically active tissue (Saba, 1970) which synthesizes proteins such as collagen, fibronectin (PFN), and factor VIII-related antigen (F VIII-R:Ag), as well as other compounds like prostaglandins. Although PFN, a high-molecular-weight glycoprotein, is mainly produced by the liver (Tamkun \& Hynes, 1983), a contribution from endothelial cells is also possible (Saba \& Jaffe, 1980; Yamada, 1983) and factors regulating PFN pool have not yet been clearly defined (Tamkun \& Hynes, 1983). Energy restriction itself alters these endotheliumassociated protein (EAP) levels, as has been found during acute starvation (Scott et al. 1982; Howard et al. 1984; Komaki et al. 1988) and in patients undergoing parenteral nutrition (Horowitz et al. 1985). On the other hand, the changes in concentrations of EAP have been related to concurrent alterations in serum thyroid hormone levels (Rogers et al. 1982; Brent et al. 1984; Graninger et al. 1985, 1986; Smallridge et al. 1985; Azuma et al. 
Table 1. Clinical features of nine anorexia nervosa patients and normal controls

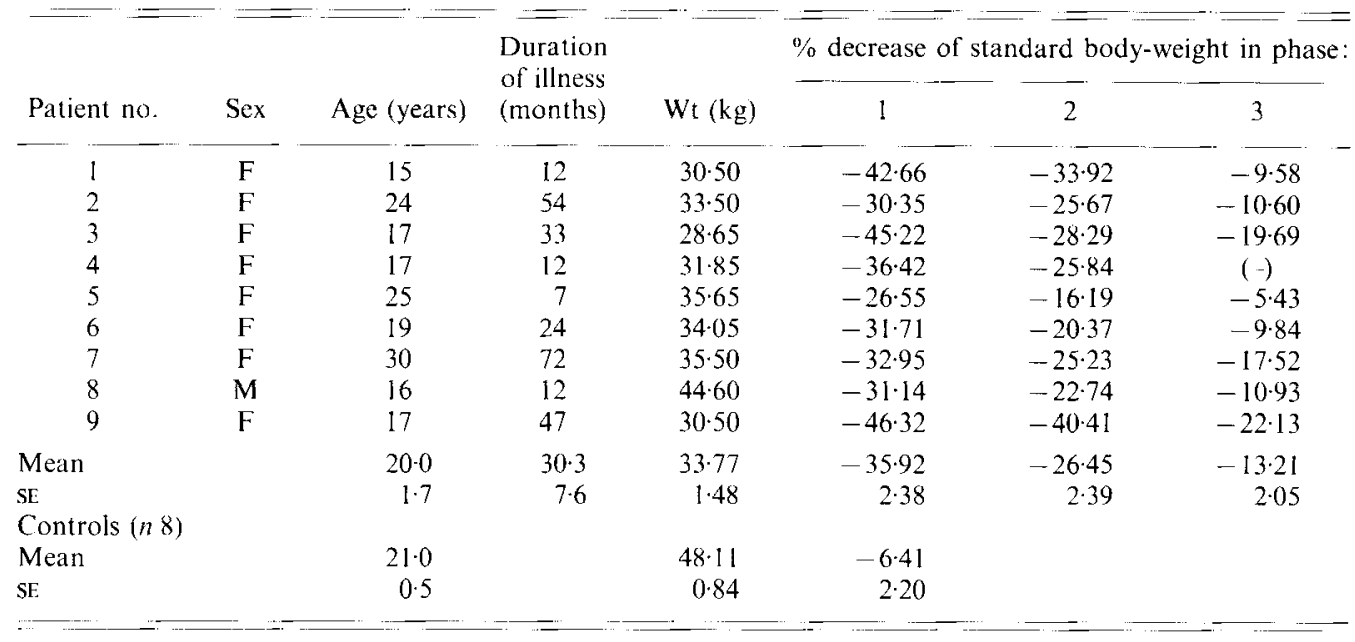

Phase $1(n 9)$, shortly after admission; phase $2(n 9)$, at the time of $5 \mathrm{~kg}$ body-weight increase $v$. phase 1 ; phase $3(n 8)$, at the time of $10 \mathrm{~kg}$ body-weight increase $v$. phase 1 .

1987). However, the interrelationships between the changes in thyroid hormone and EAP concentrations are not identical in those conditions. Furthermore, the relationship between the hormonal profile of $\mathrm{AN}$ patients and the degree of weight reduction and undernutrition is still unclear, although most endocrine alterations recover with re-feeding and weight gain (Newman \& Halmi, 1988). Therefore, serum thyroid hormone and EAP levels were measured in AN patients, when they were initially diagnosed and following restoration to normal body-weight, to gain further insight into these alterations and interrelationships.

\section{SUBJECTS AND METHODS}

\section{Subjects}

Nine hospitalized patients (eight females and one male) who met the criteria for AN according to DSMIII-R (American Psychiatric Association, 1987) were studied. Briefly, they fulfilled the following conditions: (1) refusal to maintain body-weight over a minimal normal weight-for-age and height (15\% below that expected), (2) intense fear of gaining weight or becoming fat, even though underweight, (3) disturbance in the way in which one's body-weight, size, or shape is experienced, (4) in females, absence of at least three consecutive menstrual cycles when otherwise expected to occur (primary or secondary amenorrhoea). As shown in Table 1, the mean age was 20.0 (SE 1.7) years, and the mean duration of illness was 30.3 (SE 7.6) months. On admission, mean body-weight was 33.77 (SE 1.48) kg which is -35.92 (SE 2.38 ) \% of standard body-weight for the same age, sex and height, as derived from tables of the Japanese Ministry of Health and Welfare (1986). Patients had not taken any medication for at least 2 weeks before the study. They had been continuously underweight for 6 months or more, being $25 \%$ below the standard bodyweight and with no evidence of other metabolic or endocrinological disease. Renal and hepatic function were normal and no infectious diseases were noted. There were no significant electrolyte abnormalities at the time of study in these patients. The control subjects consisted of eight age-matched healthy female volunteers. Their average age was 
21.0 (SE 0.5 ) years and their average body-weight was 48.11 (SE 0.48 ) $\mathrm{kg}$ which is 6.41 (SE 2.20$) \%$ below the standard body-weight.

\section{Study protocol}

All patients were in-patients on the ward of the Department of Psychosomatic Medicine at Kyushu University Hospital. They all gave informed consent for the study. All AN patients were treated by refeeding without medications. Weight gain was reinforced by cognitivebehaviour therapy and with continued psychotherapy. Their average energy intake commenced at 3.35-4.19 MJ/d, consisting of mixed food and tube feeding of elemental diet (Morishita Pharmaceutical Co. Ltd., Osaka), shortly after admission to the hospital. The daily diet was increased by $0.84 \mathrm{MJ}$ every $2-3$ weeks until they were ultimately eating $9 \cdot 21-10 \cdot 04 \mathrm{MJ} / \mathrm{d}$ of ordinary mixed food.

As noted in Table 1, the study was divided into three phases: phase 1 was shortly after admission; phase 2 was at the time of $5 \mathrm{~kg}$ body-weight increase; and phase 3 was when they had attained an increase of $10 \mathrm{~kg}$. Patients were weighed daily at 06.30 hours after they had voided. Most patients gained approximately $0.7-1.0 \mathrm{~kg} /$ week so phases 2 and 3 occurred at about 2 and 4 months respectively after admission to the hospital.

\section{Assays}

Serum triiodothyronine (T3) and thyroxine (T4) were measured by radioimmunoassay (RIA) (Dainabot, Matsudo City); free T3 and free T4 by RIA (Amersham International Plc, Amersham, Bucks., UK); thyroid-stimulating hormone (TSH) was measured by a highly sensitive IRMA (immuno-radiometric assay; Dainabot, Matsudo City). Thyroxinebinding protein (TBG) was measured by RIA, and assay for prealbumin was determined by the method of radial immunodiffusion. Total protein, albumin and blood chemistry studies were measured by an automated multiple-analysis system (Special Reference Laboratory, Tokyo). PFN was estimated by a kinetic immunoturbidimetric assay using rabbit antiserum against human PFN (Saba et al. 1981). Serum angiotensin-converting enzyme (ACE) was measured by a colorimetric assay (Kasahara \& Ashihara, 198I) using p-hydroxybenzoyl-glycine-L-histidyl-L-leucine as substrate (Fujebiro Pharmaceutical Co. Ltd, Tokyo). The F VIII-R: Ag concentration was measured by immunoelectrophoresis (Laurell, 1966) using anti-F VIII-R: Ag immunoglobulin G. Tissue plasminogen activator antigen (t-PA) in plasma was determined by the use of enzyme-linked immunosorbent assay (ELISA) (Bergsdorf et al. 1983).

For all assays, the intra- and interassay coefficients of variation were less than 5 and $10 \%$ respectively.

\section{Statistical analysis}

All values are expressed as means with their standard errors. Results were evaluated by means of paired and unpaired non-parametric tests (all two-tailed). Correlations between variables were determined by Spearman's correlation coefficients. The level of significance was set at $5 \%$.

\section{RESULTS}

Table 2 shows mean plasma protein and metabolite concentrations throughout the study periods. All were within the normal range and no significant changes were observed.

Table 3 shows changes in concentrations of serum thyroid hormones and TSH in AN patients during the period of study and in normal controls. Serum T3 and free T3 levels were significantly lower during the initial phase 1 compared with normal controls $(P<$ 
Table 2. Mean plasma protein and metabolite levels in nine anorexia nervosa patients before and after weight gain*

(Mean values with their standard errors)

\begin{tabular}{|c|c|c|c|c|c|c|c|c|c|c|c|c|}
\hline \multirow[b]{2}{*}{ Phase } & \multicolumn{2}{|c|}{$\begin{array}{c}\text { Serum urea } \\
\text { nitrogen } \\
(\mathrm{mmol} / \mathrm{l})\end{array}$} & \multicolumn{2}{|c|}{$\begin{array}{c}\text { Creatinine } \\
(\mu \mathrm{mol} / \mathrm{l})\end{array}$} & \multicolumn{2}{|c|}{$\begin{array}{l}\text { Total protein } \\
(\mathrm{g} / \mathrm{l})\end{array}$} & \multicolumn{2}{|c|}{$\begin{array}{l}\text { Albumin } \\
(\mathrm{g} / \mathrm{l})\end{array}$} & \multicolumn{2}{|c|}{$\begin{array}{l}\text { Prealbumin } \\
\qquad(\mathrm{g} / \mathrm{l})\end{array}$} & \multicolumn{2}{|c|}{$\begin{array}{c}\text { TBG } \\
(\mathrm{nmol} / \mathrm{l})\end{array}$} \\
\hline & Mean & $\mathrm{SE}$ & Mean & SF: & Men!n & $\mathrm{SE}$ & Mean & SE & Mean & $\mathrm{SE}$ & Mean & $\mathrm{SE}$ \\
\hline $\begin{array}{c}1 \\
(n 9)\end{array}$ & $5 \cdot 19$ & 0.38 & $62 \cdot 8$ & $3 \cdot 4$ & 70 & 2 & 44 & 1 & $0 \cdot 27$ & 0.02 & 244.5 & 16.8 \\
\hline $\begin{array}{c}2 \\
(n 9)\end{array}$ & 4.99 & 0.21 & $57 \cdot 9$ & $3 \cdot 9$ & 71 & 2 & 42 & 1 & 0.29 & 0.02 & $277 \cdot 4$ & $17 \cdot 3$ \\
\hline $\begin{array}{c}3 \\
(n 8)\end{array}$ & $5 \cdot 04$ & 0.37 & $60 \cdot 7$ & $3 \cdot 5$ & 74 & 2 & 44 & 1 & 0.29 & 0.01 & $260 \cdot 6$ & $10 \cdot 2$ \\
\hline
\end{tabular}

TBG, thyroxine-binding protein.

Phase 1, shortly after admission; phase 2, at the time of $5 \mathrm{~kg}$ body-weight increase $v$. phase 1 ; phase 3 , at the time of $10 \mathrm{~kg}$ body-weight increase $v$. phase 1 .

* For details of patients, see Table 1 ; for details of procedures, see p. 69.

Table 3. Changes in serum triiodothyronine (T3), thyroxine (T4), free T3, free T4 and thyroidstimulating hormone (TSH) in nine anorexia nervosa $(A N)$ patients before (phase 1) and during weight recovery (phases 2 and 3 ) and eight normal controls $(N C) \ddagger$

(Mean values with their standard errors)

\begin{tabular}{|c|c|c|c|c|c|c|c|c|}
\hline \multirow{4}{*}{$\begin{array}{l}\text { Phase ... } \\
n \ldots\end{array}$} & \multicolumn{6}{|c|}{ AN } & & \\
\hline & \multicolumn{2}{|c|}{1} & \multicolumn{2}{|c|}{2} & \multicolumn{2}{|c|}{3} & \multicolumn{2}{|c|}{$\mathrm{NC}$} \\
\hline & & & & & & & & \\
\hline & Mean & $\mathrm{SE}$ & Mean & $\mathrm{SE}$ & Mean & $\mathrm{SE}$ & Mean & $\mathrm{SE}$ \\
\hline T3 (nmol/1) & $0.85^{* * *}$ & $0 \cdot 07$ & $1 \cdot 24 *+1$ & 0.09 & $1 \cdot 51+1$ & 0.11 & $1 \cdot 53$ & 0.08 \\
\hline $\mathrm{T} 4(\mathrm{nmol} / \mathrm{l})$ & $79 \cdot 9$ & $8 \cdot 0$ & 90.5 & $4 \cdot 3$ & 91.0 & $5 \cdot 1$ & $99 \cdot 5$ & $5 \cdot 9$ \\
\hline Free $\mathrm{T} 3(\mathrm{pmol} / 1)$ & $2 \cdot 57 * * *$ & $0 \cdot 23$ & $3.89 *+\uparrow$ & $0 \cdot 31$ & $5 \cdot 18+t$ & 0.40 & $5 \cdot 31$ & 0.34 \\
\hline Free T4 $(\mathrm{pmol} / 1)$ & $13 \cdot 7$ & $1 \cdot 0$ & $12 \cdot 8$ & 0.5 & $13 \cdot 4$ & 0.7 & 14.8 & 0.7 \\
\hline $\mathrm{TSH}(\mathrm{mU} / 1)$ & $2 \cdot 3$ & 0.50 & $2 \cdot 28$ & $0 \cdot 30$ & $2 \cdot 17$ & $0 \cdot 31$ & 2.91 & $0 \cdot 47$ \\
\hline
\end{tabular}

Phase 1 , shortly after admission; phase 2 , at the time of $5 \mathrm{~kg}$ body-weight increase $v$. phase 1 ; phase 3 , at the time of $10 \mathrm{~kg}$ body-weight increase $v$. phase 1 .

Mean values were significantly different from those of $\mathrm{NC}:{ }^{*} P<0 \cdot 05,{ }^{* * *} P<0.00 \mathrm{I}$.

Mean values were significantly different from those of phase $1: \dagger \uparrow P<0.01$.

¥For details of patients, see Table 1 ; for details of procedures, see p. 69.

$0.001)$ and increased significantly to be within the normal range at phases 2 and 3. Serum $\mathrm{T} 4$, free T4 and TSH concentrations were within the normal range throughout the study periods (the normal ranges :T3 $1 \cdot 2-2 \cdot 8 \mathrm{nmol} / 1$, T4 $63-160 \mathrm{nmol} / 1$, free T3 4.6-7.9 $\mathrm{pmol} / 1$, free T4 $10 \cdot 3-27 \cdot 1 \mathrm{pmol} / \mathrm{l}$, TSH $0.6-5 \cdot 1 \mathrm{mU} / 1$ ).

Fig. 1 shows changes in concentration of EAPs. PFN was significantly decreased at phase $1(P<0.05)$ and subsequently increased to be within the normal range following weight gain. On the other hand, F VIII-R:Ag was significantly increased at phase 1 $(P<0.05)$ and tended to decrease during restoration of body-weight. ACE levels were not 

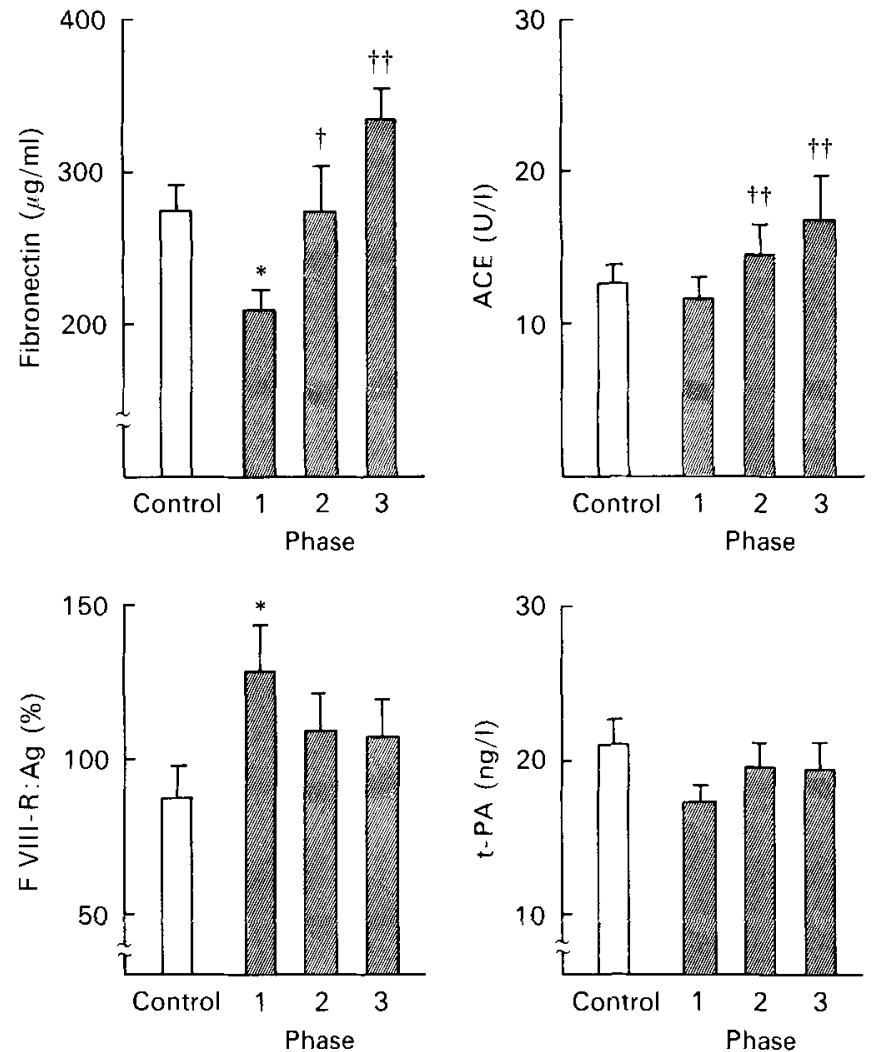

Fig. 1. Changes in plasma fibronectin, angiotensin-converting enzyme (ACE), tissue plasminogen activator (t-PA), and factor VIII-related antigen (F VIII-R:Ag) levels in nine anorexia nervosa (AN) patients before (phase 1) and during weight recovery (phases 2 and 3 ) and eight normal controls. AN patients: 1 , shortly after admission; 2 , at the time of $5 \mathrm{~kg}$ body-weight increase $v .1 ; 3$, at the time of $10 \mathrm{~kg}$ body-weight increase $v .1$. Mean values were significantly different from those of normal controls: ${ }^{*} P<0 \cdot 05$. Mean values were significantly different from those of phase 1: $\uparrow P<0.05, \dagger \dagger P<0.01$. For details of patients, see Table 1. For details of procedures, see p. 69.

significantly different from control subjects throughout the study periods, although they increased significantly following weight gain. t-PA concentrations remained normal in AN patients throughout the period of study (the normal ranges: PFN $250-460 \mu \mathrm{g} / \mathrm{ml}$, ACE 8.3-21.4 U/l, F VIII-R:Ag 50-155\%, t-PA $\leqslant 7.6 \mathrm{ng} / \mathrm{ml})$.

Significant correlations were found with PFN and thyroid hormone concentrations in patients with $\mathrm{AN}$ (phase 1 ) and normal controls ( $n$ 17, T3, $r 0.75, P<0.01$ : T4, $r 0.59, P$ $<0.05$; free T3, $r 0.72, P<0.01)$. Fig. 2 shows the relationships between PFN and serum T3 concentrations in them. Other EAPs showed, however, no significant correlations with thyroid hormones. Incremental changes (phase 2 -phase 1/phase 1) in EAPs and thyroid hormones during weight gain in AN patients are shown in Table 4. The changes of PFN correlated significantly with those of thyroid hormones $(n 9, \mathrm{~T} 3, r 0.79, P<0.01$; free T3, $r 0.84, P<0.01$ ). The same was found in the incremental changes from phase 1 to phase 3. No significant correlations were observed with the other EAPs and thyroid hormone concentrations. The change of ACE was only significantly correlated with that of bodyweight $(r 0.69, P<0 \cdot 05)$. 


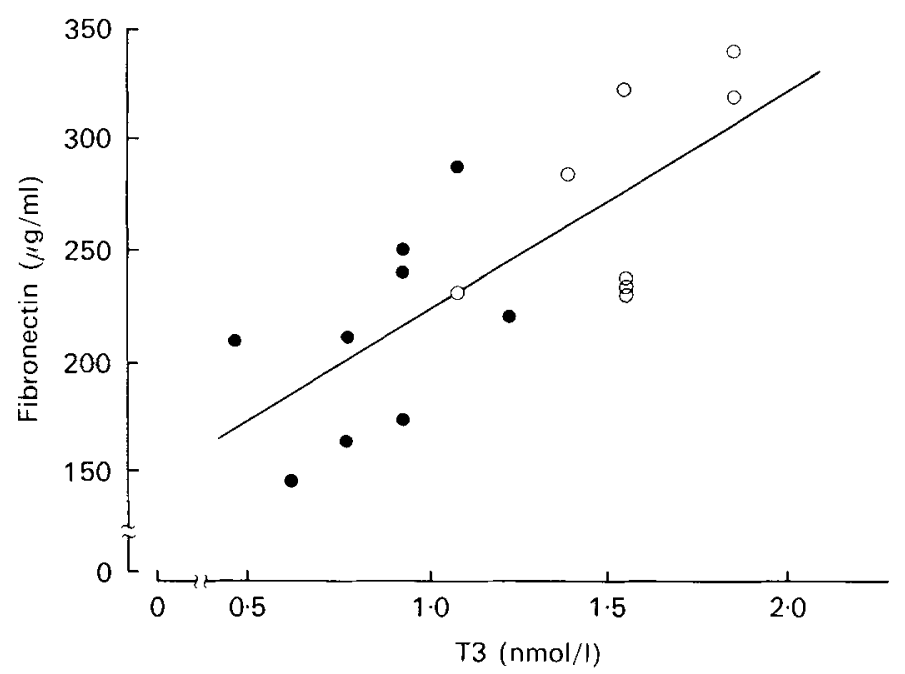

Fig. 2. The relationship between serum triiodothyronine (T3) and plasma fibronectin concentrations in nine patients with anorexia nervosa (phase 1 ; shortly after admission) (O) and eight normal controls $(O)$. The regression line $(r 0.75, P<0.01)$ : fibronectin $=98.33 \times \mathrm{T} 3+125.78$. For details of patients, see Table 1. For details of procedures, sec p. 69 .

Table 4. Correlations between incremental changes (phase 2-phase 1/phase I) in serum thyroid hormone and endothelium-associated protein (EAP) concentrations in nine anorexia nervosa patients during weight gain $\uparrow$

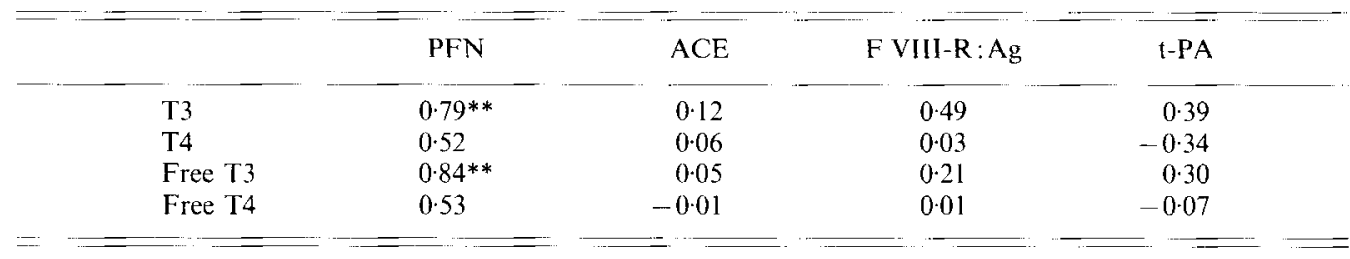

PFN, plasma fibronectin; ACE, angiotensin-converting enzyme; F VIII-R:Ag, factor VIII-related antigen; t-PA, tissue plasminogen activator; T3, triiodothyronine; T4, thyroxine,

$* * P<001$

$\dagger$ For details of patients, see Table 1 ; for details of procedures, see p. 69.

\section{DISCUSSION}

In the present study, thyroid function in $\mathrm{AN}$ patients with severe weight loss demonstrated a 'low T3' state. This finding is confirmed by previous reports on AN patients (Newman \& Halmi, 1988). The nutritional state of AN patients, however, appears to be different from protein-energy malnutrition (Ingenbleek et al. 1972; Waterlow, 1972), as indicated by concentrations of total protein and albumin as well as other rapid turnover hepaticallysynthesized proteins. Serum protein concentrations are seldom below normal in AN, and plasma aminograms have a normal appearance, which is quite unlike that observed in kwashiorkor or marasmus (Waterlow, 1972).

With regard to EAPs, PFN was significantly decreased and F VIII-R: Ag was increased when the AN patients were markedly underweight. The reductions in PFN are confirmed 
observed. This finding is similar to that reported in patients with diabetic ketoacidosis (Alexander et al. 1983), while no information was obtained regarding the correlations between PFN and serum T4 levels in those patients with a low T4 state. Based on the findings of the present study, the decreased T3 concentration can be explained by the concept 'low T3' state rather than hypothyroidism (Chopra et al. 1975). The 'low T3' state is attributed to the impairment of extravascular binding of T4 and its transport across the cell membrane, as well as to the defect of peripheral T4 conversion to T3 by 5 '-deiodinase (EC 3.8.1.4) (Van Der Hyden et al. 1986). PFN concentrations increased to be within the normal range in association with restoration of body-weight and normalization of serum T3 concentrations. Accordingly, rather than PFN being an indicator of thyroid state, the parallel changes appear to be a reflection of the nutritional and metabolic state of AN patients during weight recovery.

On the other hand, conflicting information about the influence of thyroid hormone on fibronectin synthesis was noted in several experiments. While thyroid hormones inhibit cellular-type fibronectin synthesis by cultured human skin fibroblasts (Murata et al. 1987), PFN levels are up-regulated by thyroid hormones (Graninger et al. 1985, 1986; Azuma et al. 1987). Certainly, as compared with PFN, cellular or tissue fibronectin is a less soluble form of fibronectin, localized in the extracellular matrix of many cells and in connective tissue matrices (Yamada, 1983). The major source of PFN appears to be the liver (Tamkun \& Hynes, 1983); however, factors regulating the PFN pool still remain uncertain (Yamada, 1983; Tamkun \& Hynes, 1983). In the present study it is improbable that the decreased hepatic PFN synthesis was simply attributed to the low thyroid hormone concentrations (Graninger et al. 1985) because there is not a simple cause-and-effect relationship between them (Alexander et al. 1983), and both the synthesis and catabolism of proteins are generally affected by thyroid hormones (Azume et al. 1987). Hypothyroid patients have shown rather normal PFN levels (Graninger et al. 1985). In addition, plasma concentrations of proteins known to be synthesized only by the hepatocytes were not decreased in AN patients. It seems possible that, as observed in trauma and burn patients (Saba \& Jaffe, 1980), not only synthesis but also catabolism or turnover of PFN, or both, may be changed in AN patients, thereby affecting the PFN pool. Taken together, although the elevation in PFN of AN patients during recovery may be mainly a direct reflection of increased hepatic synthesis following their ability to resume feeding, it requires further investigation to clarify the exact mechanism(s) of the synthesis and metabolism of PFN in those underweight patients.

Furthermore, all physiological functions of PFN have not been identified, although it is believed to be the primary non-specific circulating opsonin (Saba \& Jaffe, 1980). The reduction of PFN is reported in sepsis and multiple organ failure (Saba, 1986). Palmblad et al. (1977) demonstrated impaired granulocyte bactericidal capacity and reduced granulocyte adherence in AN. PFN reduction in AN may contribute, at least in part, to dysfunction in the reticulo-endothelial system, although these patients are found to be less vulnerable to infection than are those suffering from other forms of malnutrition and weight loss (Bhanji \& Mattingly, 1988). Moreover none of the patients in the present study had any evidence of infection.

Other EAPs, including ACE, have also been reported to be appropriate indicators of thyroid hormone activity (Graninger et al. 1986); however, a direct correlation with serum thyroid hormone levels was not observed in our AN patients. Only the significant correlation with body-weight change was found. This observation is supported by our previous studies of AN patients (Matsubayashi et al. 1988) and acute starvation (Komaki et al. 1988). Other factors, such as the nutritional state and weight reduction, as well as the renin-angiotensin system might modify ACE levels. 
Changes in F VIII-R:Ag activity have been also reported to correlate with thyroid function (Rogers et al. 1982; Graninger et al. 1986). In the present study, however, F VIIIR:Ag levels were increased in the 'low T3' state. Our subjects had no history of taking contraceptives. It is reported, in general, that this factor increases during the acute phase of various conditions such as malignancy, post-operative state, renal and liver disease (Lombardi et al. 1981), and during exercise (Prentice et al. 1972). Since it is recognized that many AN patients exercise vigorously (Kron et al. 1978; Bhanji \& Mattingly, 1988), the activity of our patients was closely monitored $24 \mathrm{~h} / \mathrm{d}$ on the ward to prevent hyperactivity and other various abnormal behaviours during hospitalization. However, no evidence of hyperactivity was found during this study period. Further study is necessary to clarify the mechanism of the increase in F VIII-R: $\mathrm{Ag}$ concentrations in AN.

In conclusion, these findings suggest that PFN concentrations may be directly related to those of serum T3 during weight recovery with adequate nutrition in anorexia nervosa, whereas other EAPs are changed with no obvious relationships.

\section{REFERENCES}

Alexander, C. M., Lum, S. M. C., Rhodes, J., Boarman, C., Nicoloff, J. T. \& Kumar, D. (1983). Rapid increase in both plasma fibronectin and serum triiodothyronine associated with treatment of diabetic ketoacidosis. Journal of Clinical Endocrinology and Metabolism 56, 279-282.

American Psychiatric Association (1987). Diagnostic and Statistical Manual of Mental Disorders, 3rd ed. (revised) (DSM-IIIR). Washington, DC: American Psychiatric Association.

Azuma, H., Takeichi, T., Ohara, T. \& Shirakami, A. (1987). Metabolism of plasma fibronectin in rabbits with experimental hyperthyroidism and hypothyroidism. Metabolism 36, 777-780.

Bhanji, S. \& Mattingly, D. (1988). Haematology and immunology. Medical Aspects of Anorexia Nervosa, pp. 55-62. London: Wright.

Bergsdorf, N., Nilsson, T. \& Wallé, P. (1983). An enzyme-linked immunosorbent assay for determination of tissue plasminogen activator applied to patients with thromboembolic disease. Thrombosis and Haemostasis $\mathbf{5 0}$, $740-744$.

Brent, G. A., Hershman, J. M., Reed, A. W., Sastre, A. \& Lieberman, J. (1984). Serum angiotensin-converting enzyme in severe nonthyroidal illnesses associated with low serum thyroxin concentration. Annals of Internal Medicine 100, 680-683.

Chopra, I. J., Chopra, U., Smith, S. R., Reza, M. \& Solomon, D. H. (1975). Reciprocal changes in serum concentrations of 3,3',5'-triiodothyronine (Reverse T3) and 3,3',5-triiodothyronine (T3) in systemic illness. Journal of Clinical Endocrinology and Metabolism 41, $1043-1049$.

Curran-Celentano, J., Erdman, J. W., Nelson, R. A. \& Grater, S. J. E. (1985). Alterations in vitamin A and thyroid hormone status in anorexia nervosa and associated disorders. American Journal of Clinical Nutrition $\mathbf{4 2}$, 11831191.

Graninger, W., Pirich, K., Derfler, K.\& Waldhäus!, W. (1985). Plasma fibronectin and thyroid function. Journal of Clinical Pathology 38, 64-67.

Graninger, W., Pirich, K. R., Speiser, W., Deutsch, E. \& Waldhäusl, W. K. (1986). Effect of thyroid hormones on plasma protein concentrations in man. Journal of Clinical Endocrinology and Metabolism 63, 407-411.

Horowitz, G. D., Groeger, J. S., Legaspi, A. \& Lowry, S. F. (1985). The response of fibronectin to differing parenteral caloric sources in normal man. Journal of Parenteral and Enteral Nutrition 9. 435-438.

Howard, L., Dillon, B., Saba, T. M., Hofmann, S. \& Cho, E. (1984). Decreased plasma fibronectin during starvation in man. Journal of Parenteral and Enteral Nutrition 8, 237-244.

Ingenbleek, Y., De Visscher, M. \& De Nayer, P. (1972). Measurement of prealbumin as an index of protein-calorie malnutrition. Lancet $\mathbf{i}, 106-108$.

Japanese Ministry of Health and Welfare (1986). Diagnostic Tables and Figures for Obesity and Emaciation Health Promotion and Nutrition Division, Health Service Bureau, Ministry of Health and Welfare. (In Japanese.) Tokyo: Daiichi Press.

Kasahara, Y. \& Ashihara, Y. (1981). Colorimetry of angiotensin-I converting enzyme activity in serum. Clinical Chemistry 27, 1922-1925.

Komaki, G., Tamai, H., Mori, T., Nakagawa, T. \& Mori, S. (1988). Changes in serum angiotensin-converting enzyme in acutely starved non-obese patients: a possible dissociation between angiotensin-converting enzyme and the thyroid state. Acta Endocrinologica 118, 45-50.

Kron, L., Katz, J. L., Gorzynski, G. \& Weiner, H. (1978). Hyperactivity in anorexia nervosa: a fundamental clinical feature. Comprehensive Psychiatry 19, 433-440.

Laurcll, C. B. (1966). Quantitative estimation of proteins by electrophoresis in agarose gel containing antibodies. Annals of Biochemistry 15, 45-52. 
Lombardi, R., Mannucci, P. M., Seghatchaian, M. J., Garcia, V. V. \& Coppola, R. (I981). Alterations of factor VIII von Willebrand factor in clinical conditions associated with an increase in its plasma concentrations. British Journal of Haematology 49, 61-68.

Matsubayashi, S., Tamai, H., Kobayashi, N., Takaichi, Y., Fukata, Y., Hirota, Y., Kuma, K., Nakagawa, T. \& Kumagai, L. F. (1988). Angiotensin-converting enzyme and anorexia nervosa. Hormone and Metabolic Research 20, 761-764.

Murata, Y., Ceccarelli, P., Refetoff, S., Horowitz, A. L. \& Matsui, N. (1987). Thyroid hormone inhibits fibronectin synthesis by cultured human skin fibroblasts. Journal of Clinical Endocrinology and Metabolism 64, 334339.

Newman, N. M. \& Halmi, K. A. (1988). The endocrinology of anorexia nervosa and bulimia nervosa. Endocrinology and Metabolism Clinics of North America 17, 195-212.

Palmblad, J., Fohlin, L. \& Lundstrom, M. (1977). Anorexia nervosa and polymorphonuclear (PMN) granulocyte reactions. Scandinavian Journal of Haematology 19, 334-342.

Prentice, C. R. M., Forbes, C. D. \& Smith, S. M. (1972). Rise of factor VIII after exercise and adrenalin infusion, measured by immunological and biological techniques. Thrombosis Research 1, 493-506.

Rogers, J. S. II, Shane, S. R. \& Jencks, F. S. (1982). Factor VIII activity and thyroid function. Annals of Internal Medicine 97, 713-716.

Saba, T. M. (1970). Physiology and physiopathology of the reticulo-endothelial system. Archives of Internal Medicine 126, 1031-1052.

Saba, T. M. (1986). Plasma and tissue fibronectin : its role in the pathophysiology of the critically ill septic patients. In Critical Care: State of the Art, vol. 7, pp. 437-464. [B. Chernow and W. C. Shoemaker, editors]. Fullerton, CA: Society of Critical Care Medicine.

Saba, T. M., Albert, H. W., Blumenstock, F. A., Evanega, G., Staehler, F.\& Cho, E. (1981). Evaluation of a rapid immunoturbidimetric assay for opsonic fibronectin in surgical and trauma patients. Journal of Laboratory and Clinical Medicine $\mathbf{9 8}, 482491$.

Saba, T. M. \& Jaffe, E. (1980). Plasma fibronectin (opsonic glycoprotein): its synthesis by vascular endothelial cells and role in cardiopulmonary integrity after trauma as related to reticuloendothelial function. American Journal of Medicine 68, 577-594.

Scott, R. L., Sohmer, P. R. \& MacDonald, M. G. (1982). The effect of starvation and repletion on plasma fibronectin in man. Journal of the American Medical Association 248, 2025 2027.

Smallridge, R. C., Chernow, B., Snyder, R., Zaloga, G. P. \& Burman, K. D. (1985). Angiotensin-converting enzyme activity: potential marker of tissue hypothyroidism in critical illness. Archives of Internal Medicine 145 , 1829-1832.

Tamkun, J. W. \& Hynes, R. O. (1983). Plasma fibronectin is synthesized and secreted by hepatocytes. Journal of Biological Chemistry 258, 4641-4647.

Van Der Heyden, J. T. M., Docter, R., Van Toor, H., Wilson, J. P. H., Hennemann, G. \& Krenning, E. P. (1986). Effects of caloric deprivation on thyroid hormone tissue uptake and generation of low-T3 syndrome. American Journal of Phvsiology 251, E156-E163.

Waterlow, J. C. (1972). Classification and definition of protein-calorie malnutrition. British Medical Journal 3 , $566-569$.

Yamada, K. M. (1983). Cell surface interactions with extracellular materials. Annual Review of Biochemistry 52. 761.799. 